\title{
THE TOXICOLOGY OF THE NEWER METALS
}

\author{
BY
}

\author{
LAWRENCE T. FAIRHALL
}

From the Industrial Hygiene Division, United States Public Health Service

In the following discussion of the toxicology of the ' newer' metals, it is perhaps more accurate to refer to them as metals which have only recently become of industrial importance. Most of the metals mentioned have long been known, and in some instances have actually been used in quantity. However, many new types of use have developed, or unusual compounds have become important industrially and have aroused the interest of the industrial hygienist.

It should be realized that the metals and their compounds in general have distinctive characteristics, and that it is somewhat difficult to group their physiological action in the same way as is possible with great groups of organic compounds. For instance, the nitro or amino compounds, or the halogenated hydrocarbons, have many characteristics which permit some evaluation of the toxic qualities of the individual members of the group from what we know of the group in general. The behaviour of the metals and their compounds is far less predictable from this point of view. Characteristics which belong to the group as a whole may vanish with one particular compound, or vice versa. Thus, tin salts are quite harmless. Individuals daily consume quantities of tin that would be a matter of concern if tin were as toxic as many other metals generally regarded as harmless. Yet tin tetrahydride is stated to be one of the most toxic substances, being more poisonous than arsine. The following discussion, therefore, tries to evaluate the known facts about the physiological action of the metals and their compound's as separate entities. Very little is known of some of these substances, either because they have been of no great commercial importance, or because heretofore they have not displayed properties which are distinctive in a physiological sense.

\section{Beryllium}

A few articles have been added to the recent literature concerning the industrial hazards associated with the production of beryllium, but during the past three years no work has been reported on the physiological action of beryllium itself. Shilen, Galloway, and Mellor (1944) reported the health hazards incident to the extraction of beryllium. Kress and Crispell have reported cases of chemical pneumonitis in men working with fluorescent powder containing beryllium. Van Ordstrand, Hughes, De Nardi and Carmody have recently reported the dermatological and other effects which they have observed in the beryllium industry during the past four years, and which were reported under the heading of "beryllium poisoning.' The fatal cases described in this report resulted from chemical pneumonitis. A similar chemical pneumonitis developed in an additional 33 workers at various occupations in these plants. While the hazard due to dust and fume that existed in the plants was undeniable, the term 'beryllium poisoning' is a misnomer, since no toxic action can be directly attributed to the beryllium ion itself, and the beryllium in these cases merely acted as an adjuvant.

In connexion with the manufacture of fluorescent lamps, a number of cases designated as sarcoidosis were reported in 1943 in the Massachusetts area. Since beryllium oxide is one of the constituents of the fluorescent powder, and since very little was known concerning the toxicity of beryllium, this substance was suspected as the aetiological factor in the production of sarcoidosis.

The inhalation of beryllium sulphate dust was shown to be injurious to guinea-pigs, $67 \%$ mortality in one exposure, in experimental work reported by Hyslop et al. in 1943; but, when the more neutral potassium beryllium sulphate was substituted, the animals were able to tolerate much larger doses; there was no mortality in large doses daily for seven days. Later experimental work, using rabbits, has confirmed this earlier finding.

Beryllium sulphate is so extensively hydrolysed that hydrogen is evolved when zinc is placed in a solution of the salt. It is understandable that the inhalation of beryllium sulphate dust would prove strongly irritating, owing to the local production of sulphuric acid in contact with the delicate tissue of the lung substance. The production of a pneumonitis in the victim exposed to such irritating material is readily understood. Potassium beryllium sulphate, on the other hand, is soluble in cold water, is nearly neutral in reaction, and yields all the reactions characteristic of the beryllium ion. It is not bound as a complex, which might be expected to have different properties from other beryllium salt solutions. If beryllium were a protoplasmic poison, both beryllium sulphate and potassium beryllium sulphate should show similar effects. With reference to the ulceration produced by beryllium sulphate entering cracks in the skina condition which occasionally occurs with employees handling this material-it would be of interest to try the effects of beryllium salts of more inert acids, such as beryllium citrate or beryllium malate.

\section{Cadmium}

In spite of the increased attention which has been devoted to the hygienic significance of cadmium, cases of poisoning - usually resulting from unsuspected originappear with sufficient frequency to re-emphasize the fact that cadmium is a potentially dangerous substance. The extensive report of Spolyar and his associates on cases of cadmium poisoning resulting from flanging operations on cadmium-plated pipe gives a particularly clear insight into the type of danger resulting from exposure to cadmium oxide fumes. Five cases, including one death, are summarized. On the basis of the 59 cases reported in the literature, the mortality rate of industrial cadmium poisoning appears to be $15 \%$.

As a result of cases of cadmium poisoning arising from the heating of cadmium-coated metal-with the attendant formation and volatilization of dangerous quantities of cadmium oxide-the labelling of cadmium-coated metals has been urged. While this measure is effective 
for large pieces, it is somewhat difficult to ensure that small objects so coated are labelled. A very convenient test that can be directly applied to the cadmiumcoated surface depends upon the formation of a yellow cadmium sulphide stain on the metal surface.

Cases of cadmium poisoning from careless use of vessels as beverage containers continue to be reported. In 1944 Lufkin and Hodges reported twelve men as having been affected by artificial lemonade prepared in metal containers which were later shown to be cadmiumcoated. The significant feature of cadmium poisoning by mouth is the rapidity of physiological response. The effects usually occur within 15 to 30 minutes after ingestion of food or drink containing toxic quantities of cadmium. This in itself should be suggestive in cases of so-called food poisoning. Occasionally, however, symptoms may be delayed as long as four or five hours.

Although cases of extensive cadmium poisoning have been reported from the use of cadmium-coated ice-cube containers in refrigerators, an unusual source of cadmium contamination was reported by Shiftner and Mahler in 1943 as having affected seven persons: cadmium plating of the refrigerating unit itself was responsible. Flakes of cadmium had dropped into the ice-cube compartment. A sample of ice cubes from the trays contained 769 parts per million of cadmium. A survey of apartment houses showed that $25 \%$ of the refrigerators tested had cadmium-coated parts.

Ross has recently cited a case of mass poisoning due to cadmium oxide fumes, in which 23 individuals were affected. Finely divided cadmium dust from a cadmiumrecovery chamber became ignited owing to red-hot cigarette ash carelessly dropped by one of the workers. In a few minutes the cadmium dust became incandescent, emitting clouds of cadmium-oxide fumes. Although no fatality occurred, incapacity was somewhat serious in some of the cases, disability amounting in one case to as much as two months. Ross's tabulation of the symptoms displayed by the 23 victims shows that praecordial constriction, dyspnoea, gastric pain and prostration were the predominant effects.

Delayed action is often reported to be characteristic of exposure to cadmium-oxide fume. The effects usually appear only 3 or 4 hours after exposure. The present maximum allowable concentration of cadmium fume in the atmosphere of workrooms is one milligramme per ten cubic metres of air (American Standards Association, 1941).

\section{Cobalt}

Cobalt has occupied rather a minor position in commerce; but, as new and surprising uses have developed, it has become a very important metal in industry. The amount of cobalt consumed in the United States in 1944 was practically six million pounds. Of this amount, stellite and stellite type alloys as well as carbide type alloys consumed 1,757,673 pounds. . Apart from this, its chief use was for the production of 'Alnico ' magnets (an alloy of cobalt, nickel, and aluminium). This magnet is very powerful and capable of lifting 60 times its own weight. Cobalt is extensively used as a bonding or cementing material in the manufacture of tungsten carbide and other metal carbide tool tips and dies. These bonded carbide tools have a hardness approaching that of the diamond, and are rapidly displacing highspeed steel for cutting tools. Less important uses for cobalt are to be found in certain of its alloys, such as non-corrosive and tool steels. Minor uses for certain non-metallic purposes are to be found in ground-coat frit and pigments, and in catalysts. Cobalt oxide is a very efficient catalyst for the oxidation of ammonia, and cobalt-bearing substances are in use as catalysts for the synthetic production of gasoline. A novel and to a certain extent recent use of cobalt is in soil dressings in areas where cobalt deficiency has produced such diseases in sheep and cattle as 'bush sickness,' ' salt sickness ' or 'enzoötic marasmus.'

The increasing exposure of industrial workers to cobalt metal dust or cobalt oxide dust-which has resulted from the rapid growth of the cemented tungsten carbide industry-has drawn attention to possible injurious action, both on the skin, and after inhalation of this finely-divided material. There is a substantial amount of experimental work on the physiological action of cobalt reported in the literature, and it would appear that the toxicity of cobalt by mouth is low. Antal (1894) found that a gramme of cobalt nitrate in $1 \%$ solution had no perceptible effect on rabbits, although the same quantity in $5 \%$ solution was occasionally lethal. Chittenden and Norris (1889) also observed that the poisonous action of cobalt on rabbits is slow, and apparent only after the administration of relatively large doses. Intravenously, cobalt has been observed to cause paralysis of the extremities, enteritis and death. Le Goff (1930) found that cobalt given intravenously in man produced a marked dilatation of the blood vessels of the face, with a slight fall of blood pressure.

A well-recognized effect. of the administration of cobalt salts to animals is polycythaemia, and most of the investigations relating to the physiological activity of cobalt have revolved around this phenomenon. Orten (1936) concluded that the haematopoietic activity of cobalt is the result of an increase in rate of formation of haemoglobin and erythrocytes, rather than of a passive accumulation of red cells resulting from a diminished rate of cell destruction. Frequent reference has been made to the work of Barron and Barron (1936), who state that small amounts of cobalt inhibit the respiration in vitro of various tissues-notably reticulocytes and bone marrow. However, in recent experiments Warren et al. have been unable to confirm this finding. Frost et al. found haematopoietic response at a minimum level of $1 \mathrm{mg}$. per $\mathrm{kg}$. of body weight per day when cobalt was added to iron and copper in the diet.

It has been stated recently by Griffith and others that cysteine has a detoxifying action in cobalt poisoning. According to these investigators, poisoning from cobalt may be due to fixation and loss of sulphydryl compounds in tissues, with resulting interference with oxidative mechanisms. Cobalt has been shown to produce polycythaemia in rats (Griffith et al., 1942; Orten et al. 1932; de Savitsch et al., 1936; Josland and McNaught 1938; Anderson et al., 1940; Dorrance et al., 1943), in rabbits (Barron and Barron, 1936; Kleinberg et al., 1939), in ducks (Davis et al., 1945), and in dogs (Frost et al., 1941; Brewer, 1940; Davis, 1940; Frost et al., 1941). Kent and McCance found that in man the gastrointestinal tract is the main channel of excretion for the cobalt naturally occurring in food, and that, intravenously injected, cobalt is chiefly eliminated through the kidneys. The process of elimination of cobalt from the tissues of man is very slow. In the rat cobalt is excreted chiefly in the urine, and, according to Copp and Greenberg, most of the ingested cobalt is quickly eliminated. Using radioactive cobalt, these investigators found that the amounts distributed in tissues are very small, while the bone, and the glandular organs, such as the pancreas, liver and spleen, retain the larger amount. In an investigation made in the tungsten carbide industry, Schwartz and his associates have shown that powdered cobalt produces dermatitis. Stewart has shown that, in a patient sensitive to both cobalt and nickel, hyperaemic oedematous vesicular lesions were produced by cobalt, and that the sensitivity was somewhat less than to nickel. Haxthausen has experimentally demonstrated a hypersensitivity of the skin to cobalt, while Rabeau and Ukrainczyk have been unable to confirm the reciprocal hypersensitivity of nickel-sensitive subjects to cobalt and vice versa.

\section{Columbium}

Columbium (formerly referred to as niobium) and tantalum occur in the vanadium branch of Group V, and because of the toxic effect of vanadium, it might be anticipated that exposure at least to certain of the compounds of these metals would have somewhat similar effects. Both columbium and tantalum are steel-grey 
metals having a bright metallic lustre. The similarity of chemical behaviour of the two makes quantitative separation somewhat difficult. Before the last decade neither metal had any particular importance, and both were regarded as laboratory curiosities. Columbium possesses the particular virtues of great corrosion resistance and a very high melting-point, and it is quite important at the present time as an alloy in jet-propelled airplanes, where materials are subject to terrific pressure and heat. A significant portion of the commercial output of columbium at the present time is used in the cemented carbide industry. Columbium forms a carbide which is extremely hard, and which imparts such unique properties to cemented tungsten carbide cutting tools that, in spite of the expense of columbium, it has attained commercial importance in this field as well as in that of alloy steel. There seems to have been no experimental work to indicate that exposure to columbium in any of its forms produces untoward physiological effect.

\section{Indium}

During the last few years the question of the toxicity of indium has repeatedly arisen, owing to the fact that this substance has had a number of new uses in industry. Heretofore indium had been so rare that exceedingly little had been separated and very few chemists had ever handled it. As with a number of rare metals, indium has shown such useful properties that separation of the metal and its commercial utilization have become increasingly important, particularly for plating aircraft engine bearings. These bearings of silver-lead alloy are extremely important. Silver has internal properties which resist failure due to fatigue. Externally, silver lacks the quality of oiliness needed in a good bearing surface. To fill that requirement, a thin layer of lead is applied to the silver surface. Unfortunately, lead is soluble in the organic acid present or formed in lubricating oils. Therefore indium is added-usually by electrodeposition-to the bearing surface. It prevents corrosion of the bearing surface without impairing the fatigue resistance or the bearing properties. At the same time, by increasing its wettability, indium permits the bearing surface to retain its oil film more completely. On brassbearing surfaces protected with indium, no corrosion products were in evidence after one year of use. After deposition on the metal-bearing surface, the indium is placed in an oven or hot oil bath and given about two hours of heat treatment at a temperature of $350^{\circ} \mathrm{F}$., which is slightly above the melting-point of indium. As a result of this treatment, the indium partly diffuses into the bearing metal.

In addition to the above use, indium enters into the composition of unique alloys of silver and of copper. It is a soft metal readily scratched by the thumb nail, silvery white in colour, and melting at $155^{\circ} \mathrm{C}$. It is unaffected by exposure to air. It was formerly obtained from zinc ore, but is now obtained in much larger quantities from the sludge of electrolytic copper-refining vats. Within the past few years the price of this metal has dropped from thirty dollars an ounce to four dollars an ounce.

While indium is undoubtedly toxic on intravenous or subcutaneous injection in amounts of from two to six milligrammes per kilogramme of body weight, it cannot be said to have a sufficiently high toxicity rating to be of any great industrial importance (Anon. Brit. med.J., 1943). No injury has followed the application of indium or its salts - such as indium chloride or indium sulphate-to the skin (McCord et al., 1942-3). Ingestion experiments have shown that relatively large quantities of indium salts are without toxic effect (von Oettingen, 1932).

\section{Osmium}

With the exception of osmium, the elements of the rare metal group have not received any particular attention in industrial hygiene until lately. A compound of osmium, however, osmium tetroxide, has long been recognized as dangerous. Its nauseating odour and irritating effect on the eyes are well recognized. Deville and Debray (18 $\{9)$, the first to make an extended study of the elements of this group, suffered severe injury to their eyesight as a result of exposure to osmium tetroxide fume. Owing to the restricted use of osmium-and particularly of osmium tetroxide-a relatively small group of individuals has been exposed to its effects. Nonetheless, a number of cases of severe poisoning have been reported. One authentic fatal case, resulting from the inhalation of osmium tetroxide, was reported by Raymond in 1874. The effects are acute conjunctivitis, keratitis, ulcer of the cornea, bronchitis, pneumonia, and nephritis. The severity of these symptoms depend; on the degree of exposure. Laboratory workers have occasionally complained of symptoms when handling osmium tetroxide. A few years ago, because of the blackening of osmium tetroxide in contact with oil and fat, an aqueous solution of osmic acid was used in England for finger-printing. However, it was soon realized that its use in contact with the skin caused dermatitis. The pathological changes produced in animals by exposure to osmium tetroxide have been recorded and discussed by Brunot; while McLaughlin, Milton, and Perry (1946) record d the symptoms of workers refining osmiridium In brief, the principal effects are ocular disturbances, an asthmatic condition on inhalation, and dermatitis and ulceration on skin contact.

\section{Platinum}

While the pernicious effects of osmium have beer recognized, platinum has been considered relatively harmless until very recently. During the past year (1945) Hunter and his associates published the results of their extensive investigation of four platinum refineries. They found that 52 of 91 workers exposed to the dust or spray of complex salts of platinum were subject to running of the nose, sneezing, tightness of the chest, shortness of breath, cyanosis, wheezing, and cough. Thirteen of the men complained of dermatitis. None of these symptoms was apparent in the workers exposed to metallic platinum dust only, or to the complex salts of the other precious metals, including palladium. The platinum content of air samples taken at various stations throughout the plants was determined spectrographically and found to vary from 5.0 microgrammes to 70 microgrammes per cubic metre (Fothergill et al., 1945). One may safely conclude, therefore, that platinum salts, whether carried as dust or mist, present an industrial hazard, and that such aerial contaminants should be carefully controlled.

\section{Selenium}

The literature on the toxic effect of ingested selenium is extensive because of the disastrous effects of small amounts of selenium in grain and herbage consumed by livestock in western states of the United States. A survey of the rural population in these same areas has disclosed a number of symptoms attributed to selenium intoxication, together with proof of urinary excretion of selenium (Smith et al., 1936). McConnell has shown by means of radioactive selenium that 3 to $10 \%$ of the original amount of selenium subcutaneously injected was exhaled within 24 hours. The question has been raised whether the garlicky odour in the breath of animals which have ingested selenium compounds may not be due to a trace of tellurium as an impurity. The nature of the volatile selenium compounds exhaled has not been settled, although it is generally assumed that they are di-methyl selenides or analogous substances. Selenium sulphide is highly toxic, as shown by animal experiments (Dudley and Miller, 1936-41). In man, a concentration of $0.005 \mathrm{mg}$. per litre is intolerable, producing eye and nasal irritation. The experimental work of Dudley indicates that the pathological changes following exposure to hydrogen selenide arise from a chemical pneumonitis which may persist in a sub-acute form, together with a fatty metamorphosis of the liver which tends to decrease with time. This is accompanied by a progressive change in the spleen. 
In industry, where workers have been exposed to selenium in copper refineries, a number of symptoms such as pallor, gastro-intestinal disturbances, nasal and throat irritation, garlicky odour of breath and perspiration, metallic taste, and nervousness-as well as the urinary excretion of selenium-have been reported (Dudley and Miller). While contact with metallic or amorphous selenium has not been reported as a source of skin injury, Duvoir (1937) and Pringle (1942) have reported cases of dermatitis after exposure to selenious acid and certain of its salts. The maximum allowable concentration of hydrogen selenide should be lower than the amount which produces eye or nasal irritation-i.e. less than one milligramme per cubic metre.

\section{Tantalum}

Tantalum, a rare element of Group V, is a steel-grey metal possessing a bright metallic lustre. It has a very high melting-point and is corrosion resistant. Its properties closely resemble those of columbium, so closely indeed that quantitative separation of the two is difficult. It is well known that tantalum is of use in surgery, both for sutures and for skull plates (Burke, 1940; Pudenz, 1943). Tantalum is as strong as mild steel, and is not only non-corrosive but produces no biological stimulation in contact with living tissues. The importance of tantalum in surgery is well stressed in an interesting article by Olson, who has also made the novel finding that tantalum foil, and more recently tantalum oxide dressing, is useful over burned areasparticularly with hydrofluoric acid burns, which are extremely difficult to heal. Minor uses for tantalum are its application in radar and other electronic tubes, and as a catalyst in synthetic rubber manufacture. The greater portion of the commercial output of tantalum is absorbed in the field of the cemented carbide industry. Apparently tantalum carbide imparts characteristics to carbide-cutting tools which are unique, and which make their commercial use sufficiently important to outweigh the cost of materials.

No experimental work seems to have been reported to indicate that either tantalum or its compounds produce any untoward physiological effects. Experimental work reported by Carney shows, in fact, that tantalum metal imbedded in the abdominal wall and in bones of dogs caused no physiological disturbance. The analytical separation of columbium and tantalum is particularly difficult, and the identification of either substance in small amounts is not easy, since neither forms distinctivelycoloured compounds with organic reagents specific for the substance.

\section{Tellurium}

According to Nighman the production of tellurium in the United States in 1941 amounted to 224,639 pounds, while in 1944 production has dropped to 69,025 pounds, However, producer's stocks steadily increased throughout the war period. Heretofore the principal use of tellurium has been in rubber compounding, in which, it is stated, tensile strengths are maintained at elevated temperatures and particularly good resistance to heat and ageing is obtained. It has the property of hardening lead, and it improves its resistance to acids. Minute amounts added to cast iron increase the chill depth hardness and resistance to acids. Although the amount of tellurium used in making a ton of chilled iron is small the production of chilled car wheels makes the potential requirement for tellurium in the iron industry quite large (Waitkins, Bearse, and Shutt, 1942). Tellurium is added to stainless steels to improve machineability and does not impair their corrosion resistance. Tellurium also increases the machineability of commercial bronze and is useful in alloys with tin, silver, and magnesium.

Cases of tellurium poisoning were reported as early as 1920 by Shie and Deeds. They resulted from exposure to tellurium fumes encountered as an impurity in and around blast furnaces in a silver refinery. Seven of the 13 men examined showed evidence of tellurium absorp- tion, indicated by garlic odour of breath and urine, suppression of sweat, dryness of the mouth, and metallic taste. Three of these had a dry, itching skin, anorexia, nausea, some vomiting, and some degree of depression or somnolence. Similar findings were reported by Steinberg et al. in a much more recent case of industrial exposure to tellurium. These investigators recommend that the workroom concentration of tellurium fumes should be less than the range of 0.1 to $1 \mathrm{mg}$. per 10 cubic metres of air which they encountered. Apart from those noted above, severe cases of industrial injury owing to exposure to tellurium or its compounds have not been reported in the literature. This year Keall, Martin, and Tunbridge reported two fatalities resulting from the accidental injection of sodium tellurite in place of sodium iodide.

\section{Thorium}

Although the incandescent gas mantle was more important formerly than at present, a significant amount of thorium is handled industrially at the present time, not only for the manufacture of gas mantles, but as a catalytic agent, in ceramics, and in certain pharmaceutical preparations. Thorium and its salts are only slightly poisonous. However, thorium belongs to the group of radioactive substances, and several recent references point out the danger of continued contact with thorium compounds.

In the manufacture of gas mantles a mixture of thorium and cerium nitrates in the proportion of 99 to 1 is used and from 1 to $2 \%$ of sulphuric acid is invariably added since this produces a soft, voluminous ash from six to ten times as bulky as that obtained from the pure nitrate alone. A small amount of beryllium nitrate is usually introduced, which tends to increase the hardness of the mantle. The woven material is treated with this solution, dried, and coated with collodion. In the process of preparing these mantles, workers have contracted a form of diffuse dermatitis, which was first described in this industry by Friedländer. A later case, also described by Friedländer, presented much the same features, with additional swelling of the hands and formation of deep cracks. Beyond these purely local effects, no cases of poisoning from contact with thorium compounds in industry have been reported. However, the danger of lung cancer in man following the administration of ' thorotrast ' has been referred to by Bauer, and carcinogenic effects of thorium after the administration of thorium compounds have been pointed out by Roussy and Guéren. The Journal of the American Medical Association has pointed out editorially the potential hazards of the diagnostic use of thorium dioxide. Stenstrom and Vigness have shown that certain radioactive elements in the thorium series have been found in the faeces, urine and breath of two patients six and seven years after the intravenous injection of ' thorotrast.' In these cases thorium- $X$ was found in the faeces, and thoron in the breath. Damage to the liver and spleen (Stewart et al., 1932; Huguenin et al., 1932), and fibrotic changes in regional lymph nodes (Harris and Friedrichs, 1932) have also been reported following the clinical or experimental use of thorium dioxide.

In the above discussion mesothorium has not been referred to. This substance, which is extensively used in the painting of watch and clock dials, is well known to produce severe and fatal injury (Evans, 1943). However, it is of interest that Evans and Goodman (1940), in a recent article on the thoron content of air and its relation to lung cancer, give data for the thoron conten of air in a mantle manufactory; the concentration ranged from 23 to 400 times the recommended value of $10^{-11}$ curies per litre of air for safe working conditions.

\section{Uranium}

The enormous popular interest engendered by the release of the atomic bomb has focused attention on the possible toxicity of uranium - this attention being out of all proportion to its former industrial importance. It is of course possible that, with the very active progress 
being made in the use of uranium as a source of energy, industrial exposure may be anticipated on a fairly large scale within the next few years. It should be emphasized that uranium is an extremely poisonous element. Nephritic injury similar to that produced by mercury and arsenic has long been known to result from uranium administration in animals. In general, animals poisoned with uranium show hepatic degeneration which appears to be parallel with the degree of acidosis rather than with the dose (MacNider, 1936). The chronic nephritis which occurs after the administration of uranium has been noted by a number of investigators since the first recorded study made by Leconte in 1854. Recent studies by Holman and his associates have shown that uranium produces acute necrotizing arterial lesions affecting principally the large elastic arteries. This specific injury is not confined to uranium (Holman, 1941, 1942, 1943). Although rare in man, uranium poisoning affecting four workers was reported in 1925 by de Laet. Newspaper accounts of poisoning in the manufacture of the atomic bomb have appeared, but nothing has so far been reported in the scientific literature.

Hoffmann has recently presented evidence regarding the distribution of uranium in various animal tissues: and, on the basis of this distribution, he regards it as an element essential for the life process. Holman and his associates (1944) report that sodium citrate therapy is effective in cases of uranium injury.

It should be pointed out that, since uranium hexafluoride is a volatile substance, it has practical importance in the thermal diffusion process of separation of the isotopes of uranium. Since fluorine occurs in only one atomic form, there are three possible hexafluorides of uranium. Concentration of the lightep $U-235 F_{6}$ is accomplished by diffusion through a porous barrier. The diffusion process itself is difficult, and can only be accomplished in quantity by means of the elaborate procedure adopted during the war. Information concerning the toxicity of this substance is of importance. From its physical properties and from what is known of the toxic effects of its components, it would be anticipated that uranium hexafluoride could be very toxic.

Uranium hexafluoride fumes on exposure to the air and sublimes under reduced pressure at ordinary temperatures. It boils at $56.2^{\circ} \mathrm{C}$., and has a vapour pressure of $298 \mathrm{~mm}$. at $37^{\circ} \mathrm{C}$. This substance, therefore, vaporizes easily, and care is required in order to avoid exposure. Chemically, uranium hexafluoride is highly reactive, vigorously attacking organic substances such as alcohol, ether, and benzene; in the last case it deposits carbon. It is highly corrosive to glass and metals, and one would anticipate a chemical pneumonitis, with possible additional toxic effects from inhalation of uranium hexafluoride fumes.

\section{Vanadium}

The increase in the use of vanadium in the United States is shown by the figures for production and consumption within recent years (Chem. Met. Eng., 1945). The total amount of vanadium used in industry in 1936 was 342,720 pounds, rising in 1943 to $5,179,290$ pounds (figure for domestic ore only). Since 1943 total consumption has dropped somewhat. However, it stil remains high $(4,113,309$ pounds in 1944), and doubtless will be so for some time. Vanadium is used for making special alloy steels, and is an ingredient of the best grades of high-speed steels (Johnson and Davis, 1945). While other substances exert a degasifying and deoxidizing action which aids in the formation of solid steel, vanadium is especially valuable for this purpose. It promotes fineness of grain and causes a stable solution of carbides to form in the iron matrix. The principal advantages of vanadium, however, lie in the fatigue resistance which it imparts to the alloy, in its resistance to shock impact, and in its retention of strength or hardness when hot. Apparently there is no satisfactory substitute for vanadium in the alloy steel field. Although the bulk of vanadium is used for metallurgical purposes, it has very useful applications in industry, especially as a catalyst for various chemical processes.

In common with many of the unusual metals, vanadium has been found as a constantly occurring substance in animal and plant tissues, and Bertrand suggests that it has some physiological function. However, Daniel and Hewston, using a spectrographic method of analysis, state that if vanadium functions in this manner it must do so in concentrations of less than 5 parts per million of organic content. The statistics regarding vanadium poisoning are poor, perhaps as a result of large turnover in this industry. Exposure occurs chiefly in mining and milling the ore; and, since the bulk of our vanadium ores in the past have been imported, exposure of this type has occurred in foreign countries. Patronite is the ore chiefly imported into the U.S.A. It consists mainly of vanadium sulphide. In spite of controversial statements about vanadium poisoning, there is no question but that vanadium compounds are toxic, even such substances as the crude ore dust causing striking toxic effects. This was shown in experimental work carried out in this division a short time ago. Animals were exposed to patronite dust for short periods of time of one-half to three-quarters of an hour. These animals showed a mortality of practically $100 \%$ within two to three hours after exposure. The dust is apparently extremely irritating; it causes oedema of the lungs, so that the animals die from drowning in their own tissue fluid. The best review to date of vanadium poisoning as an occupational disease is by Symanski, who has made a careful study of nineteen cases of vanadium poisoning among metallurgical employees in Germany; while Wyers (1946) has given an account of a further ten cases. Balestra and Molfino have recently reported lung damage in labourers occupied in working over petroleum ash containing vanadium. They point out that the general picture is different from that of ordinary pneumoconiosis. The potential toxicity of vanadium, together with its increasing commercial importance, suggests that it is a substance which may eventually assume marked hygienic significance.

The above summary of our knowledge of the hygiene significance of certain metals which have begun to take an important place in industry is necessarily brief. Only such references to the literature are included as would be of special interest to the industrial hygienist, and they obviously represent only a fraction of the material available. Furthermore, it will be noted that there is an occasional disparity in the amount of reference material, owing to special interest at the present time in certain of these substances, or to the fact that extensive bibliographical material is available elsewhere. The preceding discussion is intended to give information not otherwise readily obtainable regarding a number of substances with which the industrial hygienist is likely to be concerned.

\section{REFERENCES \\ BERYLLIUM}

Berkowits, F., and Izrael, B. (1940). Klin. Med. Moskva (No. 5), 18 Hyslop, F., Palmes, E. D., Alford, W. C., Monoco, A. R., and Fairhall, L. T. (1943). U.S. Natl. Inst. Health Bull. No. 181 Bibliography. (136 references).

Kress, J. E., and Crispell, K. K. (1944). Guthrie Clin. Bull., 13, 91

Meyer, H. E. (1942). Beitr. Klin. Tuberk., 98, 388. (Ind. Hyg. Foundation Translation, April, 1944.)

Shilen, J., Galloway, A. E., and Mellor, J. F., Jr. (1944). Industr. Med., 13, 464.

Van Ordstrand, H. S., Hughes, R., De Nardi, J. M., and Carmody M. G. (1945). J. Amer. med. Ass., 129, 1084

Wurm, H., and Rüger, H. (1942). Beitr. Klin .Tuberk., 98, 396

\section{Cadmium}

American Standards Association. Allowable Concentration of Cadmium. (1941). Z37, 5. 
Anon. (1942). Publ. Hlth Repts. Wash., 57, 601. Reprint No. 2371 -Cadmium Poisoning. F. T. (1944). U.S. Nav Med Bull 43

Ross, Philip (1944). Brit. med. J., 1, 252. (Includes 23 industrial

cases.)
Shiftner, J. J., and Mahler, H. (1943). Amer. J. publ. Hlth., 33, 1224. Spolyar, L. W., Keppler, J. F., and Porter, H. G. (1944). J. industr. Hyg., 26, 232.

\section{Cobalt}

Anderson, H. D., Underwood, E. J., and Elvehjem, C. A. (1940). Amer. J. Physiol., 130, 373.

Antal, J. (1894). Russ. Pharm. J., 33, 518

Barron, A. G., and Barron, E. S. G. (1936). Proc. Soc. exp. Biol. N.Y., 35, 407.

Brewer, G. (1940). Amer. J. Physiol., 128, 345.

hittenden, R. H., and Norris, C. (1889). The Relative Absorption of Nickel and Cobalt. Studies Iab. Physiol. Chem. Yale Univ., $3,148$.

Copp, D. H., and Greenberg, D. M. (1941). Proc. Nat. Acad. Sci.,

Davis, J. E. (1940). Amer. J. Physiol., 129, 140. McCullough, A. W., and Rigdon, R. H. (1945). J. Lab. clin. Med., 30, 327.

de Savitsch, E., et al. (1936). Amer. J. Roentgen., 35, 786.

Dorrance, S. S., Thorn, G. W., Clinton, M., Jr., Edmonds, H. W., and Farber, S. (1943). Amer. J. Physiol., 139, 399.

Friend, J. N. (1941). J. Soc. Chem. Ind., 60, 643.

Frost, D. V., Elvehjem, C. A., and Hart, E. B. (1941). J. Nutrit., 21,

-, Spitzer, E. H., Elvehjem, C. A., and Hart, E. B. (1941). Amer. Griffith, W. H., Pavcek, P. L., and Mulford, D. J. (1942). J. Nutrit., 3,603

Haxthausen, H. (1936). Arch. Derm. Syph:, Berlin, 174, 17.

Josland, S. W., and McNaught, K. J. (1938). N. Z. J. Sci. Tech., 19

Kent, N. L., and McCance, R. A. (1941). Biochem. J., 35, 837.

Kleinberg, W., Gordon, A. S., Charipper, H. A. (1939). Proc. Soc.

exp. Biol., N.Y., 42, 119

Lé Goff, J. M. (1930). J. Pharmacol., 38,

McLaren, D. C. (1943). Canad. Min. J., 64, 341.

rten, J. M., Underhill, F. A., Mugrage, E. R., and Lewis, R. C. (1932). J. Biol. Chem., 96, 11.

Rabeau, H., and Ukrainczyk (1938). Bull. Soc. franç. Derm. Syph.,

45, 1872.
Schwartz, L., Peck, S. M., Blair, K. E., and Markuson, K. E. (1945). J. Allergy, 16, 51

Shils, M. E., and McCollum, E. V. (1942). J. Amer. med. Ass., 120 . (Contains a bibliography.)

Stewart, S. G. (1933). Arch intern. Med 51, 427.

Warren, C. O., Schubmeht, Q. D., and Wood, I. R. (1944). Amer. $142,173$.

\section{Columbium}

Balke, C. W. (1944). Trans. Electrochem. Soc., 85, 25.

Burch, J. N. (1945). National Safety News, 52, Sept. 12

Rudorf, D. W. (1943). Metals and Alloys, 17, 186.

\section{INDIUM}

Anon. (1943). Brit. med. J., 1, 793

P. Chem Ed 21, 407. Ludwick, M. T. A Bibliography of Indium, 1934-1942. The Indium Corporation of America. C. P., Meek, S. F., Harrold, G. C., and Heussner, C. E Murray, W.S. (1946). N.Y. Mechanical Engineering, 68, 43.

von Oettingen, W. F. (1932). Proc. Soc. exp.Biol., N.Y., 29, 1188

\section{OSMIUM}

Brunot, F. R. (1933). J.industr. Hyg., 15, 136.
Deville and Debray. (1859). Ann. Chem., 56, 385.

Davis, H. W., and Greenspoon, G. N. "Platinum and Allied Metals.' Minerals Yearbook, 1944. U.S. Bureau of Mines, Washington, D.C.

Gilchrist, R. (1943). Chem. Rev., 32, 277-372. (Bibliography-813 references.)

McLaughlin, A. I. G., Milton, R., and Perry, K. M. A. (1946).

Raymond, F.(1874).
Winkler, O. (1945).
Metals and Alloys, 21, 194.

\section{Pi ATINUM}

Beamish, F. E., and Warren, E. W. (1942). Canad. Min. J., 63,

Davis, H. W., and Greenspoon, G. N. 'Platinum and Allied Metals.' Minerals Yearbook, 1944. U.S. Bureau of Mines, Washington, D.C.

Fothergill, S. J. R., Withers, D. F., and Clements, F. S. (1945).

Gilchrist, R. (1943). Chem. Rev., 32, 277. (Bibliography-813

references.)
Hunter, D., Milton, R., and Perry, K. M. A. (1945). Brit. J. industr. med., 2, 92.

\section{SELENIUM}

Challenger, F. (1945). Chem. R., 36, 315. (Bibliography-219 Dudley, H. C. (1936). Amer. J. Hyg., 23, 169, 181; 24, 227.

.., and Miller, I. W. (1937). Publ. hlth. Reps. Wash., 52, 1217 (Keprint No. 1855.)
Dudley, H. C. (1938). Ibid., 53, 94 . (Reprint No. 1901.) and Miller, J. W. (1941). J. industr. Hyg., 23, 470.
(1938). Publ. Hlth. Reps., Wash., 53, 281. (Reprint No. 1910.)

Duvoir, M., Pollet, L., and Herrenschmidt, J. L. (1937). Bull. Soc franç. Derm. Syph., 44,88.

Fitzhugh, S. G., Nelson, A. A., and Bliss, C. I. (1944). J. Pharm.

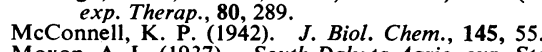

Moxon, A. L. (1937). South Dakota Agric. exp. Sta. Bull.

-, and Rhian, M. (1943). Physiol. Rev., 23, 305. (Bibliography

Nighman, C. E. (1944). ' Minor Metals.' Minerals Yearbook. U.S Bureau of Mines, Washington, D.C

Pringle, P. (1942). Brit. J. Derm. Syph.54, 54

Smith, M. I., Franke, K. W., and Westfall, B. B. (1936). Publ. Hlth. Reps., Wash., 51, 1496. (Reprint No. 1780.)

- Westfall, B. B., and Stohlman, E. F. (1938). Ibid., 53, 1199.

$-, \frac{174}{-},-$, and Lillie, R. D. (1940). Nat. Inst. Hlth. Bull., No. (1941). J. Amer. med. Ass., 116, 562.

Waitkins, G. R., Bearse, A. E., and Shutt, R. (1942). Ind. Eng. Chem., 34, 899. (Bibliography-143 references.)

\section{TANTALUM}

Burch, J. N. (1945). National Safety News, 52, Sept. 12.

Burke, G. L. (1940). Canad. med. Ass. J., 43, 125.

Carney, H. M. (1942). Proc. Soc. exp. Biol., N.Y., 51, 147.

Crump, H., and Miller, P. (1945). Prod. Engng., 16, 217.

Olson, C. T. (1944). Industr. Med., 13, 917.

(1945). lbid. 14, 949.

Pudenz; R. H. (1943). J. Amer. med. Ass., 121, 478.

TELLURIUM

Challenger, F. (1945). Chem. Rev., 36, 315. (Bibliography-219 Keall, J. H. H., Martin, N. H., and Tunbridge, R. E. (1946). Brit. J. industr. med., 3, 175

Mead, L. T., and Gies, W. J. (1901). Amer. J. Physiol., 5, 104

Nighman, C. E. Minerals Yearbook, 1944. U.S. Bureau of Mines

Shie, M. D., and Deeds, F. E. (1920). Publ. Hlth. Reps., Wash., 35,

Steinberg, H. H., Massari, S. C., Miner, A. C., and Rink, R. (1942).

Waitkins, G. R. Bearse, A. E., and Shutt, R. (1942). Ind. Engng. Chem., 34, 899. (Bibliography-143 references.)

\section{THORIUM}

Andervont, H. B., and Shimkin, M. B. (1940). J. nat. Cancer Inst. $1,349$.

Bauer, K. H. (1943). Chirurg., 15, 204.

Collins, D. C. (1939). Canad. med. Ass. J., 40; 440.

Correspondence. (1940). Brit. med. J., 1, 368, 504

Editorial. (1940). Ibid., 1, 222

Editorial. (1937). J. Amer. med. Ass., 108, 1656.

Evans, R. D., and Goodman, C. (1940). J. industr. Hyg., 22, 89

(1943). Ibid., 25, 253

Foulds, L. (1939). Amer. J. Cancer, 35, 363.

Friedländer, W. (1912). Arch. Derm. Svph., Chicago, 113, 359.

Harris, W. H., and Friedrichs, A. V. (1932). Proc. Soc. Exp. Biol. N.Y., 29, 1047.

Huguenin, R., Nemours-Auguste, and Albot, G. (1932). Ann. d'Anat. Path., 9, 263.

Jacobson, L. E., and Rosenbaum, A. (1938). Radiology, 31, 601.

Roussy, G., and Guéren, M. (1941). Presse Méd., 49, 761.

Stenstrom, W., and Vigness, I. (1940). Proc. Soc. exp. Biol., N.Y., $44,18$.

- (1941). Radiology, 37, 698

Stewart, W. H., Einhorn, M., and Illick, H. E. (1932). Amer. J.

Roentgen., 27, 53.
Stuck, R. M., and Reeves, D. L. (1938), Arch. Neurol. Psychiat. Chicago, 40, 86 .

\section{URANIUM}

De Laet, M. (1925). Report of Fourth International Congress on C'ccupational Accidents and Diseases. Amsterdam.

Dement, J., and Dake H. C. Uranium and Atomic Power. Chem. Pub. Co., Brooklyn, N.Y. Second Ed. 1945.

Donnelly, G. L., Ross, C. J., Meroney, W. H., and Holman, R. L. (1944). Proc. Soc. Exp. Biol., N.Y., 57, 75.

Editorial Staff Summary. (1945). Chem. metall. Engng., 52, 102.

Hoffmann, Josef. (1943). Biochem. Z., 313, 377.

(1943). Ibid. 315, 26.

Holman, R. L. (1941). Am. J. Path., 17, 359.

Hewitt, W. C. (1942). Proc. Soc. exp. Biol., N.Y., 49, 58 (1943). Amer. J. Path., 19, 147.

- , and Douglas, W. A. (1944). Proc. Soc. exp. Biol., N.Y. 57, 72

Leconte, C. (1854). Gaz. d. Rop., Paris, 27, 157.

MacNider, W. de B. (1936). J. Pharmacol. exp. Therap., 56, 359.

\section{VANADIUM}

Balestra, G., and Molfino, F. (1942). Rass. Med. Lav. industr., 13, 5 Bertrand, D. (1942). C. R. Acad. Sci., Paris, 215, 150

(1943). Bull. Soc. Chim. biol., Paris, 25, 36.

Daniel, E. P., and Lille, R. D. (1938). Publ. Hlth. Rep., Wash., 53,

and Hewston, E. M. (1942). Amer. J. Physiol., 136, 772.

Jenckes, E. K., and van Siclen, A. P. (1944). 'Vanadium.' Minerals Yearbook. U.S. Bureau of Mines, Washington, D.C

Johnson, A. C., and Davis, C. W. (1945). Engng. Mining J., 146, 105.

Molfino, F. (1938). Arch. Sci. med., 66, 287.

Symanski, H. (1939). Arch. Gewerbepath. Gewerbehvg., 9, 295.

Wyers, H. (1946). Brit. J. industr. med., 3, 177. 